\title{
Depth-dependent photoacclimatization to solar ultraviolet radiation in the Caribbean coral Montastraea faveolata
}

\author{
Michael P. Lesser* \\ Department of Zoology and Center for Marine Biology, University of New Hampshire, Durham, New Hampshire 03824, USA
}

\begin{abstract}
The importance of solar ultraviolet radiation (UVR, 290 to $400 \mathrm{~nm}$ ), and UVB (290 to $320 \mathrm{~nm}$ ) in particular, as an environmental factor affecting the biology and ecology of coral reefs has taken on renewed interest since the demonstration of global stratospheric ozone loss through human activities. The hermatypic coral Montastraea faveolata occurs over a wide bathymetric range in the Florida Keys reef tract. The bathymetric range of $M$. faveolata and its role in reef community structure make it an important species for which to assess the effects of present day UVR irradiances. Both UVR irradiances and UVR-absorbing mycosporine-like amino acids (MAAs) decreased significantly with increasing depth in $M$. faveolata. UVB irradiances were measured to a depth of $30 \mathrm{~m}$ during this study and maximum rates of productivity in $M$. faveolata were significantly affected by the presence of UVR. Action spectra (= biological weighting function) for the photoinhibition of photosynthesis by UVR were measured for samples of $M$. faveolata at $3,10,18,23$, and $30 \mathrm{~m}$. Using these action spectra, radiation amplification factors (RAFs) were calculated for corals at the same depths. RAFs for M. faveolata suggest that corals at depths greater than $3 \mathrm{~m}$ will be more sensitive to increases in UVB irradiance, such as might be caused by ozone depletion, than their shallow-water counterparts. Despite this increase in sensitivity to UVB, calculations incorporating continued ozone depletion suggest that at the present rate of stratospheric ozone depletion corals deeper than $5 \mathrm{~m}$ in the Florida Keys will be affected very little, if at all, by increases in UVR. These results, however, do not incorporate the interacting and synergistic effects of UVR with other physical parameters (e.g. temperature) that will be essential to understanding and predicting the fate of coral reefs under conditions of global change.
\end{abstract}

KEY WORDS: Corals $\cdot$ Ozone depletion $\cdot$ UVR $\cdot$ Action spectra $\cdot$ Photosynthesis

\section{INTRODUCTION}

Hermatypic scleractinian corals are abundant in nutrient-poor, tropical waters exposed to high irradiances of solar radiation, especially the ultraviolet radiation (UVR) portion of the spectrum. Although heterotrophy plays an important role in the feeding biology of many species of coral, the principal input of carbon for corals is thought to come from autotrophic processes via their endosymbiotic dinoflagellates (= zooxanthellae; Muscatine 1990). This dependence on autotrophy underscores the importance of

•E-mail:mpl@christa.unh.edu the light environment in the physiology and ecology of corals (Dustan 1982, Dubinsky et al. 1984, Porter et al. 1984, Porter 1985, Battey \& Porter 1988, Falkowski et al. 1990).

Recently, decreases in the concentration of stratospheric ozone as a result of anthropogenic inputs of chlorinated fluorocarbons have caused an increase in the amount of UVR, specifically UVB, reaching the sea surface. Earlier concerns about seasonal ozone depletion were centered on the Antarctic. The combination, however, of a smaller solar zenith angle and a thinner layer of ozone near the equator (Cutchis 1982) exposes tropical ecosystems to irradiances of total UVR, and UVB in particular, higher than those observed in the Antarctic (Green et al. 1974, Frederick et al. 1989). 
From 1979 to 1993 UVB radiation, biologically weighted using the Setlow (1974) DNA weighting function, increased at $5^{\circ} \mathrm{S}$ and $5^{\circ} \mathrm{N}$ latitude by $5.1 \pm$ $2.3 \%(\mathrm{SD})$ and $4.1 \pm 2.7 \%$ respectively, and DNAweighted doses at $15^{\circ} \mathrm{S}$ and $15^{\circ} \mathrm{N}$ latitude increased by $2.8 \pm 2.1 \%$ and $6.3 \pm 2.4 \%$ respectively (Madronich et al. 1995). Many subtropical and tropical coral reefs (Bahamas, Caribbean, Hawaii, northern Red Sea) lie within these latitudes. Furthermore, the data predict that UVB irradiances in these regions could increase in the future before the present day rates of stratospheric ozone loss begin to level off and decrease in the next half-century (Madronich et al. 1995).

In general, the high transparency of tropical ocean waters allows biologically effective UVR to penetrate to depths of $20 \mathrm{~m}$ or more (Jerlov 1950, Smith \& Baker 1979. Fleischman 1989, Gleason \& Wellington 1993, Shick et al. 1996). UVR, especially UVB, is known to have a detrimental effect on photosynthesis and growth in zooxanthellae (Jokiel \& York 1982, 1984, Lesser \& Shick 1989, Lesser 1996), the survival of corals (Siebeck 1988) and coral reef epifauna (Jokiel 1980). The harmful effects of UVR may involve damage to DNA, various proteins, and membrane lipids (see Shick et al. 1996 for review). For the Hawailan coral Pocillopora damicornis, exposed to sequentially greater portions of the solar UVR spectrum, there are significant decreases in the maximum rates of photosynthesis (Lesser \& Lewis 1996). Jokiel \& York (1982) also observed decreases in the rates of calcification and photosynthesis in $P$. damicornis when exposed to UVR. Gross photosynthesis in the Hawaiian coral Montipora verrucosa decreases after long-term acclimatization to UVR (Kinzie 1993) despite an increase in the concentration. of UVR-absorbing compounds known as mycosporine-like amino acids (MAAs). Studies on the Great Barrier Reef have shown that paired specimens of the coral Acropora microphthalma transplanted from 10,20 , and $30 \mathrm{~m}$ depth to $2 \mathrm{~m}$ depth maintain similar rates of photosynthesis when shielded from UVR, while unshielded specimens exhibit a significanl depression in photosynthesis during exposure to UVR (Shick et al. 1995).

An important response of corals during exposure to UVR includes the synthesis of MAAs that protect both the host and 5 mbiont from the detrimental effects of UVR. MAAs provide a broad-band filter that is believed to provide protection from the high energy wavelengths within the UV part of the spectrum. A protective role for these compounds has been inferred from their UVR-absorbing properties (Gleason 1993) and their decrease in concentration with increasing depth (Dunlap et al. 1986, Jokiel et al. 1997). Experiments where MAA concentrations reflect treatments with and without artificial shielding from UVR (Jokiel
\& York 1982, Scelfo 1986, Shick et al. 1991) have also been used to infer a protective role for these compounds. It has also been shown that varying irradiances of photosynthetically active radiation (PAR: 400 to $700 \mathrm{~nm}$ ) and differences in water flow can affect the concentration of MAAs in the tissues of corals, and all 3 environmental factors (UVR, PAR, and water flow) co-vary with depth (Jokiel et al. 1997).

In order to predict the effects of further increases in UVB radiation on the productivity and ecological structure of aquatic primary producers, the biological effects of UVR and the ability of organisms to acclimatize should be understood and quantified. Although the irradiance of UVR is low, less than $5 \%$ of the spectrum (UVR, PAR, and infrared) reaching the biosphere, the high energy photons of these shorter wavelengths have greater biological effects. The biologically weighted dose for UVR exposure is the integral of the incident UVR irradiance multiplied by a biological weighting function for some process of interest. A biological weighting function describes the wavelength-dependent effects for that irradiance or dose of UVR. Constructing biological weighting functions is important for accurate predictions and modeling (Smith et al. 1980, Caldwell et al. 1986, Coohill 1989) in the event that changes in the rate and extent of ozone depletion continue. Biological weighting functions can then be used to develop radiation amplification factors (RAFs). RAFs represent the increment of biological damage associated with a specific decrease in ozone concentration and are used to make predictions about the sensitivity of a biological response to future changes in stratospheric ozone. A RAF is computed, using the weighting function for the biological response of interest, for small (usually $1 \%$ ) decreases in stratospheric ozone using a full radiative transfer calculation for atmospheric properties (e.g. aerosols, albedo effects, and ozone concentration) and solar zenith angle for a specific geographic location (Madronich 1994).

This paper presents a study on the UVR photobiology of the coral Montastraea faveolata at Conch Reef, Key Largo, Florida. Using biological weighting functions and RAFs for the photoinhibition of photosynthesis in this coral over its bathymetric distribution, predictions on the effects of future decreases in stratospheric ozone over subtropjcal areas on photosynthesis are presented.

\section{MATERIALS AND METHODS}

Study site. Conch Reef (Pinnacle Site) is a fringing reef approximately $8 \mathrm{~km}$ southeast of Key Largo, Florida $\left(24^{\circ} 58^{\prime} \mathrm{N}, 80^{\circ} 27^{\prime} \mathrm{W}\right)$ within the Florida Keys 
National Marine Sanctuary. The reef is characterized by coral spur and groove formations that run from the reef crest to a depth of 12 to $\sim 30 \mathrm{~m}$ where the spur and groove breaks up into isolated patch reefs surrounded by carbonate sand at approximately $35 \mathrm{~m}$. The study was conducted in August 1994 using Nitrox (Nitrox II, $36 \% \quad \mathrm{O}_{2}$ ) and saturation diving from the Aquarius underwater habitat provided by the National Undersea Research Center, Key Largo, Florida. Samples of the coral Montastraea faveolata were identified using the characteristics described in Knowlton et al. (1992) and Weil \& Knowlton (1994) over a depth range of 3 to $30 \mathrm{~m}$

Spectroradiometery. Visible radiation and UVR (300 to $700 \mathrm{~nm}$ ) were measured on several days during the period of August 10 to 28, 1994. Spectral irradiance data at each depth were obtained using a Li-Cor LI1800UW scanning spectroradiometer (Li-Cor, Lincoln, Nebraska) calibrated with National Institute of Standards and Technology (NIST) traceable standards. The cosine-corrected collector and sensors were programmed to scan from 300 to $700 \mathrm{~nm}$ in $2 \mathrm{~nm}$ intervals. The sensor has a $50 \%$ detection range of $\pm 2 \mathrm{~nm}$ on either side of the wavelength being measured, and minimum excitation energies on the order of $10^{-8} \mathrm{~W}$ $\mathrm{cm}^{-2} \mathrm{~nm}^{-1}$. At each deployment depth, hourly readings consisting of 3 separate scans (total scan time approximately $45 \mathrm{~s}$ ) were collected and the mean reported in units of $W \mathrm{~m}^{-2} \mathrm{~nm}^{-1}$. Despite the $8 \mathrm{~nm}$ bandwidth of this instrument, which tends to smooth sharp peaks, comparison testing has shown good agreement with radiative transfer models and other commercial underwater instruments for measurements in the UV portion of the spectrum (Kirk et al. 1994). Some investigators have expressed reservations about the use of single monochromators for underwater spectral measurements (Dunne \& Brown 1996). Recent testing, however, continues to show that, when measuring the same UVR source under similar conditions, the single monochromator and filter wheel combination (LI-1800UW) gives comparable results to a double monochromater system, especially in the area of stray light rejection, wavelength accuracy, and total irradiance. The differences in the comparable portion of the UVB spectrum (300 to $320 \mathrm{~nm}$ ) of the LI-1800UW and a calibrated double monochromater system with a photomultiplier tube and fiber optics (EG\&G Inc.) amount to 6-7\% whether comparing integrated values or averaging differences from 300 to $320 \mathrm{~nm}$ in $2 \mathrm{~nm}$ intervals (M. P. Lesser unpubl. data). This difference is well within radiative transfer model errors associated with estimating ambient UVR, and errors associated with the calibration of the instruments. Additional spectral data, using the same type of instrument, were obtained from Dr G. M.
Wellington and the UV monitoring system on Key Largo, Conch Reef. Vertical attenuation coefficients $\left(K_{d} \mathrm{~m}^{-1}\right)$ for both visible and UVR were calculated as described by Kirk (1994b).

Oxygen flux. Colonies ( $\mathrm{N}=6$ ) of Montastraea faveolata were collected from each depth $(3,10,18,23$, and $30 \mathrm{~m}$ ), cleaned of all epibionts, and allowed to 'heal' for $48 \mathrm{~h}$ at their depth of occurrence (corals were placed on PVC collars to keep the samples off of the substratum). Additionally, another set $(N=6)$ of corals was collected from $30 \mathrm{~m}$ (38:1, PAR:UVR ratio) and transplanted to $18 \mathrm{~m}(12: 1$, PAR:UVR ratio) for a period of $1 \mathrm{wk}$ to simulate an increase in visible and UVR irradiances. Samples from each depth $(N=6)$ were then placed in a self-contained, multichambered $(N=6)$, underwater respirometer at the depth of collection, except for transplants which were collected at $30 \mathrm{~m}$ and run at $18 \mathrm{~m}$, for 24 to $36 \mathrm{~h}$ to obtain oxygen flux and underwater irradiance data. Briefly, the chambers are approximately $15 \mathrm{~cm}$ in diameter and $20 \mathrm{~cm}$ tall with a volume of $3.7 \mathrm{l}$. The chambers and lids are made of Plexiglas that transmits UVR $(100 \%$ cutoff at $275 \mathrm{~nm}, 50 \%$ cutoff at $305 \mathrm{~nm})$. All chambers are constantly stirred using hydraulically driven magnetic stirrers, and flushed at 60 min intervals to prevent supersaturation of the seawater with oxygen during the day. Changes in oxygen concentration were measured using calibrated Cameron Instruments E101 polarographic electrodes. The oxygen electrode polarization and the pump and solenoid controls were provided on a custom-designed printed circuit (Pamunkey Engineering Associates) in an Ikelite U/W housing. Data were collected and stored using a Li-Cor 1000 datalogger, also located in the Ikelite U/W housing, then downloaded to a computer as a text file and converted to oxygen concentrations and fluxes. The oxygen flux within each chamber was corrected for the volume displacement of each individual coral. PAR (400 to $700 \mathrm{~nm}$ ) was recorded simultaneously with the oxygen flux measurements using an underwater cosine-corrected sensor (Li-Cor LI192SA) at the depth of incubation. Ambient temperatures at all depths ranged from 29 to $30^{\circ} \mathrm{C}$ during the day as measured by a series of recording temperature thermistors placed at each depth on an anchored mooring line with a buoy (HOBO Temps, Onset Corporation). Photosynthesis and respiration were normalized to colony surface area determined immediately after removal from the respirometer using the aluminum foil technique (Marsh 1970), where the surface area of the coral is directly related to the weight, determined using regression analysis, of a piece of aluminum foil completely covering the surface of the coral. Additionally, coral plugs $\left(3.0\right.$ to $\left.5.0 \mathrm{~cm}^{2}\right)$ were obtained using a drill stand and $2.54 \mathrm{~cm}$ diameter 
wood plug bit and subsequently analyzed for chl a. Coral plugs from each depth $(\mathrm{N}=6)$ were placed overnight in $100 \%$ acetone at $4^{\circ} \mathrm{C}$. The trichromatic equations of Jeffrey \& Humphrey (1975) were then used to calculate the concentrations of chl a.

Action spectra and radiation amplification factors. Additional coral samples $(\mathrm{N}=6)$ from each depth were collected for action spectra measurements of photosynthesis. For this analysis, in addition to the Plexiglas lids that transmit UVR for each chamber of the respirometer, individual long-band pass filters (Schott, WG series) were fitted over the respirometer chambers for action spectra measurements that progressively exclude UVR while keeping visible radiation constant. The long-band pass filters were $16.5 \mathrm{~cm}$ square and $3.0 \mathrm{~mm}$ thick with a nominal cutoff $(50 \%)$ at 280,295 , $305,320,375$, and $395 \mathrm{~nm}$ as described in Lesser \& Lewis (1996). The action spectra resulting from this polychromatic approach (Caldwell et al. 1986) are more ecologically relevant when examining UVRinduced inhibition of photosynthesis, since photoinhibition is the net result of damage and repair processes (Lesser et al. 1994), where repair processes are often dependent on the presence of visible radiation. The action spectrum (= biological weighting function) for Montastraea faveolata at each depth was constructed initially by modeling net photosynthesis to irradiance (i.e. $P$-I curves) to characterize photoinhibition by UVR for each filter treatment. Initial plots of the raw data showed no sensitivity to irradiances greater than saturation as is commonly observed in phytoplankton. Consequently, using least squares criterion, the hyperbolic tangent $P$-I model $\left[P_{1}=P_{\mathrm{s}} \tanh \left(\alpha I / P_{\mathrm{s}}\right)\right]$ of Jassby $\&$ Platt (1976) was used iteratively to non-linearly regress the oxygen flux data normalized to surface area to PAR. From these data the maximum photosynthetic capacity, $P_{\max }\left(\mu \mathrm{mol} \mathrm{O}_{2} \mathrm{~cm}^{-2} \mathrm{~h}^{-1}\right)$, was derived for each coral. In the model, $P_{1}\left(\mu \mathrm{mol} \mathrm{O}_{2} \mathrm{~cm}^{-2} \mathrm{~h}^{-1}\right)$ is the instantaneous rate of photosynthesis normalized to surface area at irradiance $i_{i} P_{3}\left(\mu \mathrm{mol} \mathrm{O}_{2} \mathrm{~cm}^{-2} \mathrm{~h}^{-1}\right)$ is the maximum rate of photosynthesis; and $\alpha\left(\mu \mathrm{mol} \mathrm{O}_{2} \mathrm{~cm}^{-2}\right.$ $\mathrm{h}^{-1}$ [umol quanta $\left.\mathrm{m}^{-2} \mathrm{~s}^{-1} \mathrm{~J}^{-1}\right)$ is the initial slope of the P-I curve.

The $P_{\max }$ data and maximum irradiance of total UVR were then used to obtain the differential irradiance of UVR between successive filters and the differential biological response (photoinhibition) as described by Rundel (1983) to obtain the average action spctrum for cach WC filter. These datu were then interpolated from 280 to $400 \mathrm{~nm}$ at $1 \mathrm{~nm}$ intervals, normalized to 1 at $290 \mathrm{~nm}$, and fit to the exponential equation $\varepsilon(\lambda)=\exp \left(a_{0}+a_{1} \lambda+a_{2} \lambda^{2}\right)$ as described in Rundel (1983). The exponential fits represent the action spectrum for the photoinhibition of photosynthesis at each depth.
Using the calculated action spectra, a RAF was then determined from 280 to $420 \mathrm{~nm}$ for each depth in $1 \mathrm{~nm}$ intervals using atmospheric profiles from US Standard Atmospheric continental aerosols with $25 \mathrm{~km}$ visible range and TUV 3.9 radiative transfer model as described by Madronich $(1993,1994)$. These RAFs are applicable to the latitude of the study site and midday solar UVR exposures assuming clear skies and similar optical properties of the water column.

Mycosporine-like amino acids. For all coral samples, the extraction and analysis of MAAs were performed according to the procedures in Dunlap \& Chalker (1986) as modified by Shick et al. (1992). For analysis by high performance liquid chromatography (HPLC), coral samples from each depth $(\mathrm{N}=6)$ were cleaned of epiphytes, broken into small pieces, and extracted overnight in $5 \mathrm{ml}$ of $100 \%$ HPLC grade methanol at $4{ }^{\circ} \mathrm{C}$. The extracts were centrifuged and the supernatant used for MAA and protein analysis. Individual MAAs were separated by reverse-phase, isocratic HPLC on a Brownlee RP-8 column (Spheri-5, $4.6 \mathrm{~mm}$ i.d. $\times 250 \mathrm{~mm}$ ) which was protected with an RP8 guard column (Spheri-5, $4.6 \mathrm{~mm}$ i.d $\times 30 \mathrm{~mm}$ ). The mobile phase consisted of 40 to $55 \%$ methanol (v:v), $0.1 \%$ glacial acetic acid $(v: v)$ in water and run at a flow rate of $0.6 \mathrm{ml} \mathrm{min}^{-1}$ Detection of MAA peaks was by UV absorbance at 313 and $340 \mathrm{~nm}$. Standards were available for 7 MAAs (mycosporine-glycine, shinorine, porphyra-334, palythine, asterina-330, palythinol, and palythene). Identities of peaks were confirmed by cochromatography with standards, and the ratios of $313 \mathrm{~nm}$ to $340 \mathrm{~nm}$ absorbances. Peaks were integrated and quantification of individual MAAs was accomplished using HPLC peak areas and calibration factors determined by analysis of the standards listed above. All MAAs were normalized to soluble protein from an aliquot of the methanol-extracted sample and concentrations are expressed in $\mu \mathrm{g}$ MAA $\mathrm{mg}^{-1}$ protein. Protein measurements were determined using the procedure of Bradford (1976)

Statistical analysis. Chlorophyll concentrations normalized to surface area, calculated $P$-I parameters, and the MAA concentrations were statistically analyzed using a 1-way ANOVA (fixed effect of depth) at a significance level of $5 \%$. All analyses were conducted on the same set of corals from each depth. No unequal variances were detected using the $F_{\text {max }}$ test, and individual treatment differences were assessed using the Student-Nowman-Kculs (SNK) multiple comparison test. Linear, multiple, and stepwise regression analyses (Model I) were performed to assess the relationship between total MAA concentration (nmol MAA mg protein $^{-1}$ ) and UVR irradiance (integrated between 300 and $400 \mathrm{~nm}, \mathrm{~W} \mathrm{~m}^{-2}$ ) over the bathymetric range of Montastraed faveolata in this study. 


\section{RESULTS}

\section{Characterization of the underwater light field}

A profile of bathymetric measurements of the underwater light field taken on Conch Reef in August, at the smallest solar zenith angle (ca 13:00 h), show that UVB radiation does transmit through the water column of this reef down to $30 \mathrm{~m}$ (Fig. 1, $310 \mathrm{~nm}$ minimum wavelength at $30 \mathrm{~m}$ ). August values of integrated irradiances for UVA, UVB, and PAR for each depth throughout the day (07:00 to 19:00 h), compiled from $7 \mathrm{~d}$ of cloud-free measurements during the study period, exhibit an exponential decline in irradiance with depth for all portions of the spectrum (Table 1). The greater attenuation of the underwater spectrum in the short- and long-wavelength portions of the spectrum is a consistent feature of coastal waters that was observed on Conch Reef (Fig. 1) and is also reflected in the spectral attenuation coefficients shown in Fig. 2. The coefficients $\left(K_{\mathrm{d}}\left[\mathrm{m}^{-1}\right]\right)$ observed for the UVB portion of the spectrum on Conch Reef $(0.18$ to 0.28 at $320 \mathrm{~nm})$ during the experimental period fall between those measured for Kaneohe Bay, a tropical estuary $\left(K_{\mathrm{d}}\left[\mathrm{m}^{-1}\right]\right)$ of 1.0 at $320 \mathrm{~nm}$ ), and Moku Manu, an offshore Hawaiian reef $\left(K_{\mathrm{d}}\left[\mathrm{m}^{-1}\right]\right)$ of 0.20 at 320$)$ (Shick et al. 1996).

\section{Effects of UVR on photosynthesis}

The calculated $P$ - $I$ parameters from the in situ oxygen flux measurements for the corals exposed to full spectrum (290 to $700 \mathrm{~nm}$ ) underwater irradiances varied significantly with depth. Maximum rates of productivity declined significantly with increasing depth $\left(P_{\max }\right.$, Table 2, 1 -way ANOVA, $\mathrm{df}=5,12, F$-value $=154 ;$ $\mathrm{p}=0.0001$ ). Photosynthesis in corals transplanted from 30 to $18 \mathrm{~m}$ was significantly reduced when compared to $30 \mathrm{~m}$ corals (Table 2 ; SNK: $\mathrm{p}<0.05$ ), a change consistent with exposure to both higher PAR and UVR during the transplant period. Alpha ( $\alpha$, Table 2$)$, the lightlimited portion of the $P$ - $I$ curve, increased significantly with depth (1-way ANOVA, df =5, 12, F-value 67, $\mathrm{p}=$ 0.0001 ) as did the amount of $\mathrm{chl} \mathrm{a} \mathrm{cm}^{-2}$ (Table 2; 1 -way ANOVA, df $=5,12, F$-value $=333, p=0.0001)$. These results suggests that Montastraea faveolata photoacclimatized to changes in the underwater light field associated with changing depth. The decrease in $\alpha$ and chl $a \mathrm{~cm}^{-2}$ in the corals transplanted from 30 to $18 \mathrm{~m}$ (Table 2) is also consistent with the depression of maximum photosynthesis observed in the transplanted corals. The results for the transplanted corals suggest that increased PAR and UVR irradiances significantly depressed both light harvesting and maximum photosynthetic capacity in corals transplanted to shallower

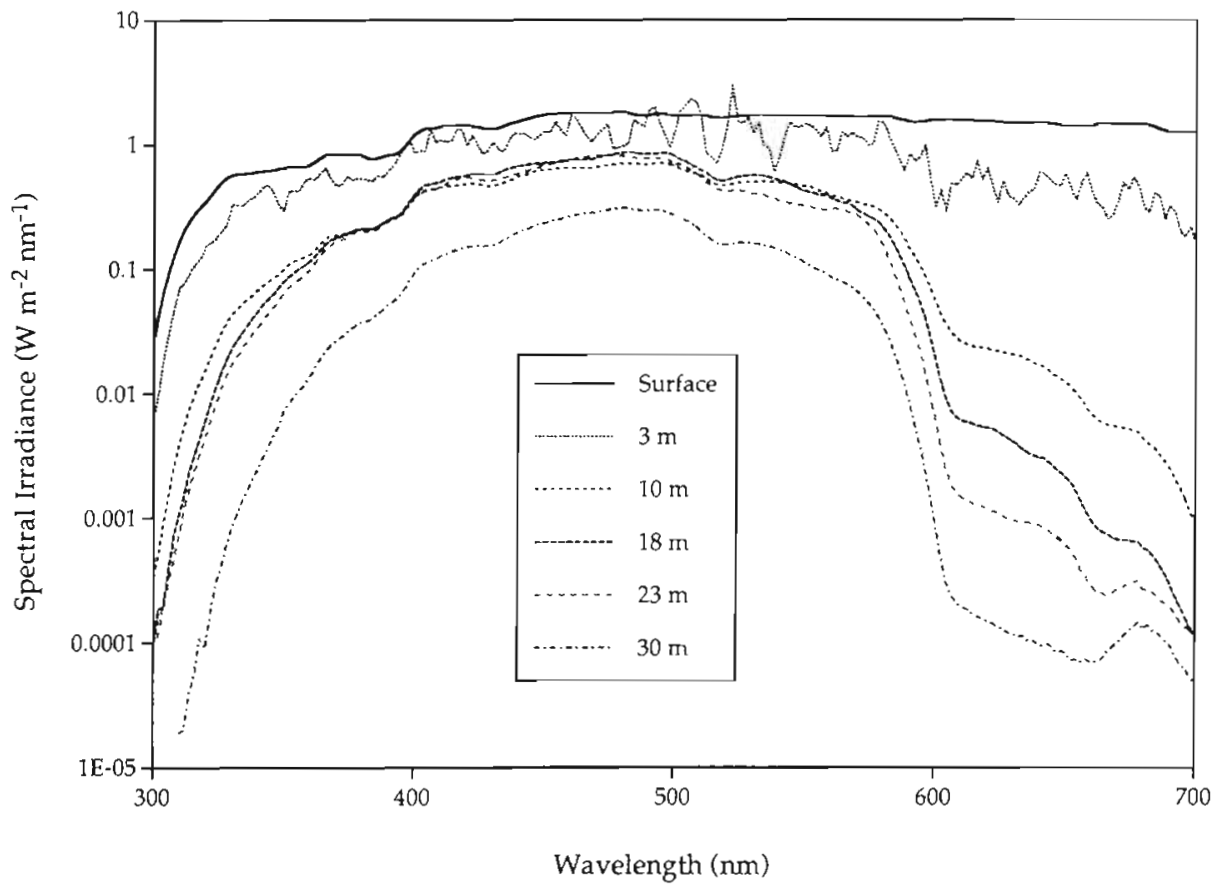

Fig. 1. Depth profile of spectral data (300 to $700 \mathrm{~nm}$ ) recorded on Conch reef, Key Largo, Florida, August 1994 (ca 13:00 h), using a Li-Cor LI-1800UW scanning spectroradiometer (Li-Cor, Lincoln, Nebraska) placed at the various depths using SCUBA. The time between scans was approximately 3 to $4 \mathrm{~min}$. Curves represent the means of 3 scans for each depth 
Table 1. Integrated spectral irradiance at (a) $3 \mathrm{~m}$, (b) $10 \mathrm{~m}$, (c) $18 \mathrm{~m}$, (d) $23 \mathrm{~m}$ and (e) $30 \mathrm{~m}$ for visible and UV radiation on Conch Reef, Florida Keys, August 1994. nd: none detected

\begin{tabular}{|c|c|c|c|c|}
\hline Time (h) & $\begin{array}{l}\mathrm{UV}\left(\mathrm{W} \mathrm{m}^{-2}\right) \\
300-400 \mathrm{~nm}\end{array}$ & $\begin{array}{l}\mathrm{UVB}\left(\mathrm{W} \mathrm{m}^{-2}\right) \\
300-320 \mathrm{~nm}\end{array}$ & $\begin{array}{l}\operatorname{PAR}\left(\mathrm{W} \mathrm{m}^{-2}\right) \\
400-700 \mathrm{~nm}\end{array}$ & $\begin{array}{c}\text { PAR }\left(\mu \mathrm{mol} \text { quanta } \mathrm{m}^{-2} \mathrm{~s}^{-1}\right) \\
400-700 \mathrm{~nm}\end{array}$ \\
\hline \multicolumn{5}{|l|}{ (a) $3 \mathrm{~m}$} \\
\hline 07:00 & 0.3785 & 0.001682 & 3 & 10 \\
\hline $08: 00$ & 5.085 & 0.07252 & 42 & 158 \\
\hline 09:00 & 10.03 & 0.2420 & 72 & 265 \\
\hline $10: 00$ & 21.79 & 0.6225 & 182 & 692 \\
\hline $11: 00$ & 24.60 & 0.8751 & 220 & 849 \\
\hline $12: 00$ & 32.72 & 1.118 & 281 & 1085 \\
\hline $13: 00$ & 40.31 & 1.343 & 326 & 1243 \\
\hline $14: 00$ & 36.37 & 1.165 & 306 & 1175 \\
\hline $15: 00$ & 33.47 & 0.8312 & 286 & 1094 \\
\hline $16: 00$ & 24.64 & 0.5816 & 247 & 964 \\
\hline $17: 00$ & 18.26 & 0.3462 & 198 & 777 \\
\hline $18: 00$ & 11.36 & 0.2024 & 111 & 426 \\
\hline $19: 00$ & 3.864 & 0.04377 & 36 & 135 \\
\hline \multicolumn{5}{|l|}{ (b) $10 \mathrm{~m}$} \\
\hline $07: 00$ & nd & nd & nd & nd \\
\hline 08:00 & 1.606 & 0.00658 & 17 & 65 \\
\hline $09: 00$ & 1.982 & 0.01378 & 19 & 71 \\
\hline $10: 00$ & 4.259 & 0.03225 & 41 & 150 \\
\hline $11: 00$ & 7.451 & 0.06067 & 71 & 262 \\
\hline $12: 00$ & 15.13 & 0.1315 & 141 & 518 \\
\hline $13: 00$ & 11.75 & 0.110 & 112 & 413 \\
\hline $14: 00$ & 8.892 & 0.0817 & 75 & 269 \\
\hline $15: 00$ & 7.630 & 0.07263 & 67 & 242 \\
\hline $16: 00$ & 4.911 & 0.03699 & 45 & 163 \\
\hline $17: 00$ & 4.935 & 0.04355 & 43 & 156 \\
\hline $18: 00$ & 2.956 & 0.01937 & 26 & 95 \\
\hline $19: 00$ & 1.329 & 0.005204 & 11 & 4 \\
\hline \multicolumn{5}{|l|}{ (c) $18 \mathrm{~m}$} \\
\hline $07: 00$ & nd & nd & nd & nd \\
\hline $08: 00$ & 1.044 & 0.007081 & 12 & 45 \\
\hline $09: 00$ & 2.431 & 0.002987 & 31 & 115 \\
\hline $10: 00$ & 4.658 & 0.007168 & 56 & 210 \\
\hline $11: 00$ & 6.905 & 0.01311 & 87 & 323 \\
\hline $12: 00$ & 7.561 & 0.01692 & 98 & 368 \\
\hline $13: 00$ & 9.970 & 0.02614 & 119 & 444 \\
\hline $14: 00$ & 10.29 & 0.02759 & 120 & 446 \\
\hline $15: 00$ & 8.026 & 0.01846 & 100 & 371 \\
\hline $16: 00$ & 5.318 & 0.008929 & 73 & 273 \\
\hline $17: 00$ & 3.575 & 0.004942 & 49 & 185 \\
\hline $18: 00$ & 2.065 & 0.003749 & 26 & 96 \\
\hline $19: 00$ & 0.5834 & 0.0009924 & 8 & 28 \\
\hline \multicolumn{5}{|l|}{ (d) $23 \mathrm{~m}$} \\
\hline 07.00 & nd & nd & nd & nd \\
\hline 0800 & 0.4196 & 0.0003823 & 7 & 27 \\
\hline 0900 & 1.371 & 0.001087 & 20 & 73 \\
\hline $10: 00$ & 3.413 & 0.004117 & 44 & 161 \\
\hline $11: 00$ & 7.163 & 0.01702 & 75 & 272 \\
\hline $12: 00$ & 8.026 & 0.02149 & 85 & 308 \\
\hline 13.00 & 1002 & 0.03561 & 110 & 394 \\
\hline 14.00 & 10.89 & 0.03452 & 109 & 393 \\
\hline $15: 00$ & 6.945 & 0.01726 & 77 & 280 \\
\hline $16: 00$ & 0.5360 & 0.0005808 & 13 & 52 \\
\hline 17.00 & 0.4649 & 0.0001647 & 10 & 40 \\
\hline $18: 00$ & 0.3309 & nd & 9 & 36 \\
\hline $19: 00$ & 0.03853 & nd & 1 & 4 \\
\hline
\end{tabular}


Table 1 (continued)

\begin{tabular}{|c|c|c|c|c|}
\hline Time $(h)$ & $\begin{array}{l}\mathrm{UV}\left(\mathrm{W} \mathrm{m}^{-2}\right) \\
300-400 \mathrm{~nm}\end{array}$ & $\begin{array}{l}\text { UVB }\left(\mathrm{W} \mathrm{m}^{-2}\right) \\
300-320 \mathrm{~nm}\end{array}$ & $\begin{array}{l}\text { PAR }\left(\mathrm{W} \mathrm{m}^{-2}\right) \\
400-700 \mathrm{~nm}\end{array}$ & $\begin{array}{c}\text { PAR }\left(\mu \mathrm{mol} \text { quanta } \mathrm{m}^{-2} \mathrm{~s}^{-1}\right) \\
400-700 \mathrm{~nm}\end{array}$ \\
\hline \multicolumn{5}{|l|}{ (e) $30 \mathrm{~m}$} \\
\hline $07: 00$ & nd & nd & $\mathrm{nd}$ & nd \\
\hline 08:00 & 0.1767 & 0.0002122 & 7 & 25 \\
\hline $09: 00$ & 0.2990 & 0.0003380 & 10 & 43 \\
\hline $10: 00$ & 0.2868 & 0.0004295 & 11 & 46 \\
\hline $11: 00$ & 0.3342 & 0.0005142 & 12 & 48 \\
\hline $12: 00$ & 0.4802 & 0.0008321 & 15 & 61 \\
\hline $13: 00$ & 0.8992 & 0.0008440 & 35 & 135 \\
\hline $14: 00$ & 0.6523 & 0.0007738 & 24 & 86 \\
\hline $15: 00$ & 0.5874 & 0.0005753 & 16 & 62 \\
\hline $16: 00$ & 0.5001 & 0.0004365 & 15 & 60 \\
\hline $17: 00$ & 0.4662 & 0.0003251 & 8 & 31 \\
\hline
\end{tabular}

Table 2. Summary of areal chlorophyll a values and calculated photosynthesis-irradiance parameters from full spectrum (290 to $700 \mathrm{~nm}$ ) in situ and transplant ( $30 \mathrm{~m}$ to $18 \mathrm{~m}$ ) measurements for Montastraea faveolata, Conch Reef, Florida Keys, August 1994. Significant treatment effects (= depth) were detected for chlorophyll, normalized to surface area, and each photosynthetic parameter (ANOVA, p < 0.05), common superscripts denote groups not significantly different from one another (SNK, $p<0.05)$

\begin{tabular}{|lcccc|}
\hline Depth $(\mathrm{m})$ & Chl $a \mathrm{~cm}^{-2}( \pm \mathrm{SD})$ & $\begin{array}{c}P_{\max }( \pm \mathrm{SD}) \\
\left(\mu \mathrm{mol} \mathrm{O} \mathrm{cm}^{-2} \mathrm{~h}^{-1}\right)\end{array}$ & $\begin{array}{c}\alpha( \pm \mathrm{SD}) \\
\left(\mu \mathrm{mol} \mathrm{O} \mathrm{cm}^{-2} \mathrm{~h}^{-1}\left[\mu \mathrm{mol} \text { quanta } \mathrm{m}^{-2} \mathrm{~s}^{-1}\right)^{-1}\right)\end{array}$ & $\begin{array}{c}\mathrm{R}( \pm \mathrm{SD}) \\
\left(\mu \mathrm{mol} \mathrm{O}_{2} \mathrm{~cm}^{-2} \mathrm{~h}^{-1}\right)\end{array}$ \\
\hline 3 & $4.98 \pm 0.48^{\mathrm{A}}$ & $3.10 \pm 0.17^{\mathrm{A}}$ & $0.011 \pm 0.002^{\mathrm{A}}$ & $-0.06 \pm 0.16^{\mathrm{A}}$ \\
10 & $5.15 \pm 0.52^{\mathrm{A}}$ & $2.12 \pm 0.14^{\mathrm{B}}$ & $0.011 \pm 0.002^{\mathrm{A}}$ & $-0.02 \pm 0.13^{\mathrm{A}}$ \\
18 & $13.49 \pm 0.23^{\mathrm{B}}$ & $1.48 \pm 0.12^{\mathrm{C}}$ & $0.058 \pm 0.014^{\mathrm{B}}$ & $-0.43 \pm 0.12^{\mathrm{B}}$ \\
23 & $15.14 \pm 0.37^{\mathrm{C}}$ & $1.88 \pm 0.14^{\mathrm{B}}$ & $0.102 \pm 0.020^{\mathrm{C}}$ & $-0.08 \pm 0.14^{\wedge}$ \\
30 & $16.72 \pm 0.59^{\mathrm{D}}$ & $1.93 \pm 0.07^{\mathrm{B}}$ & $0.139 \pm 0.015^{\mathrm{D}}$ & $-0.11 \pm 0.06^{\mathrm{A}}$ \\
$30 \rightarrow 18$ & $14.55 \pm 0.66^{\mathrm{C}}$ & $0.44 \pm 0.03^{\mathrm{D}}$ & $0.007 \pm 0.001^{\mathrm{A}}$ & $-0.02 \pm 0.03^{\mathrm{A}}$ \\
\hline
\end{tabular}

depths. Respiration ( $R$, Table 2) rates also varied significantly with depth (1-way ANOVA, df = 5, 12, F-value $=5$, $\mathrm{p}=0.008$ ), but no interpretable pattern associated with depth was evident. Similar results have been observed for the effects of depth or UVR on respiration in other studies (Shick et al. 1996).

\section{Bathymetric distribution of mycosporine-like amino acids}

Six individual MAAs were identified in all samples of Montastraea faveolata (Fig. 3A). Mycosporine-glycine was present in the highest concentration at all depths (Fig. 3A), and decreased significantly with depth (1-way ANOVA, $\mathrm{df}=4,25, F$-value $=13, \mathrm{p}<0.0001)$ in an exponential fashion. The concentration of mycosporine-glycine from corals

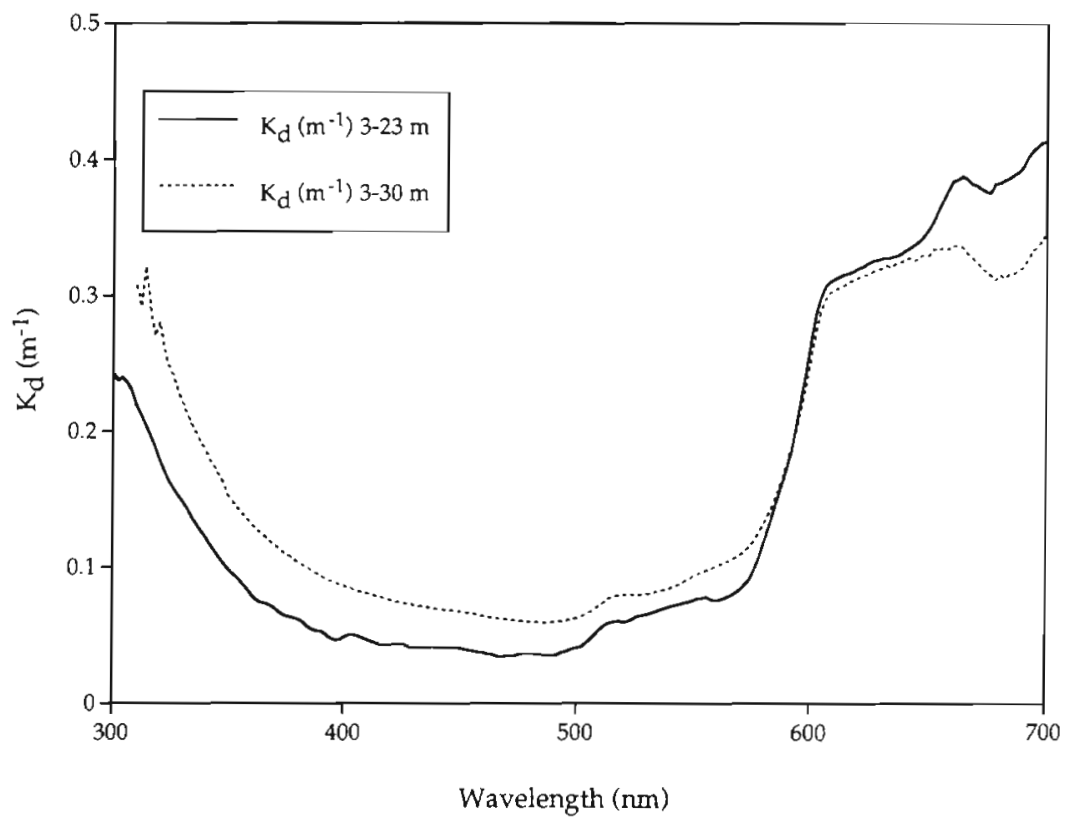

Fig. 2. Attenuation coefficients $\left[K_{d}\left(\mathrm{~m}^{-1}\right)\right]$ using the spectral data $(300$ to $700 \mathrm{~nm}$ ) recorded on Conch Reef, Key Largo, Florida, August 1994 
A

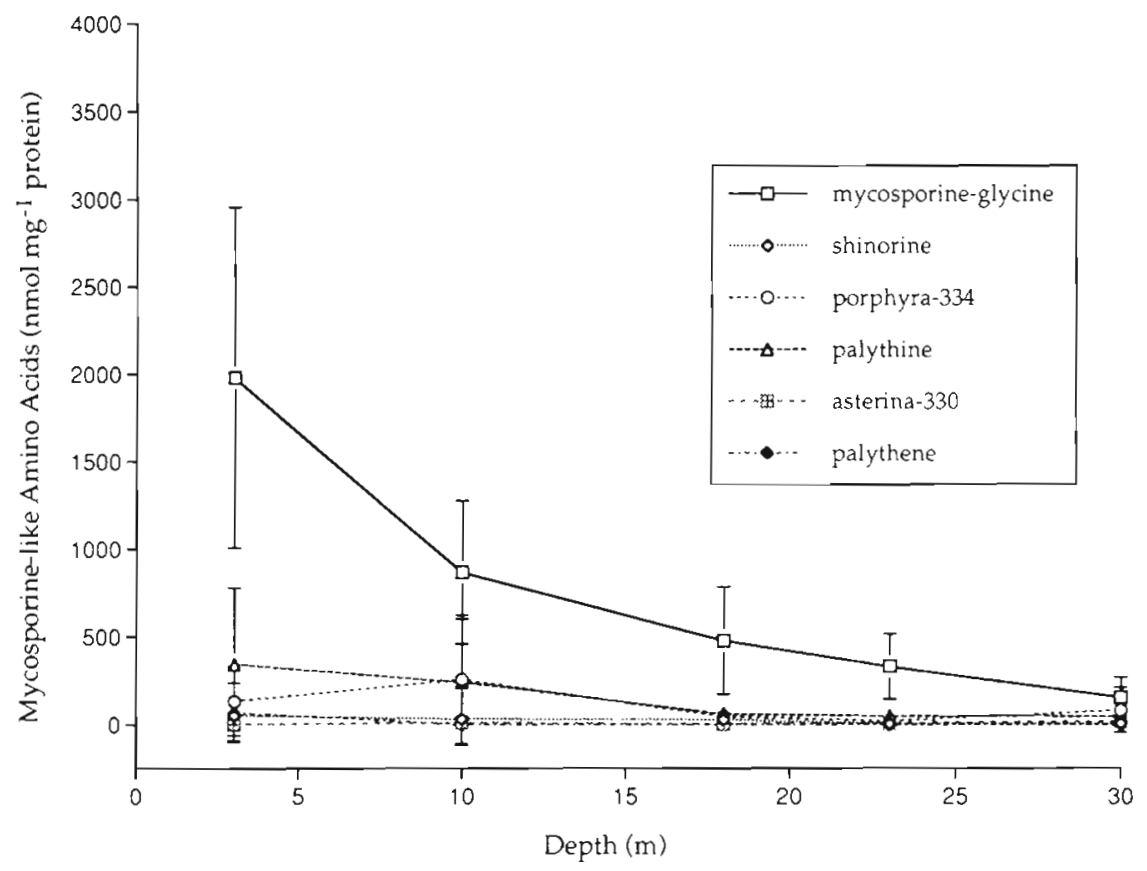

B

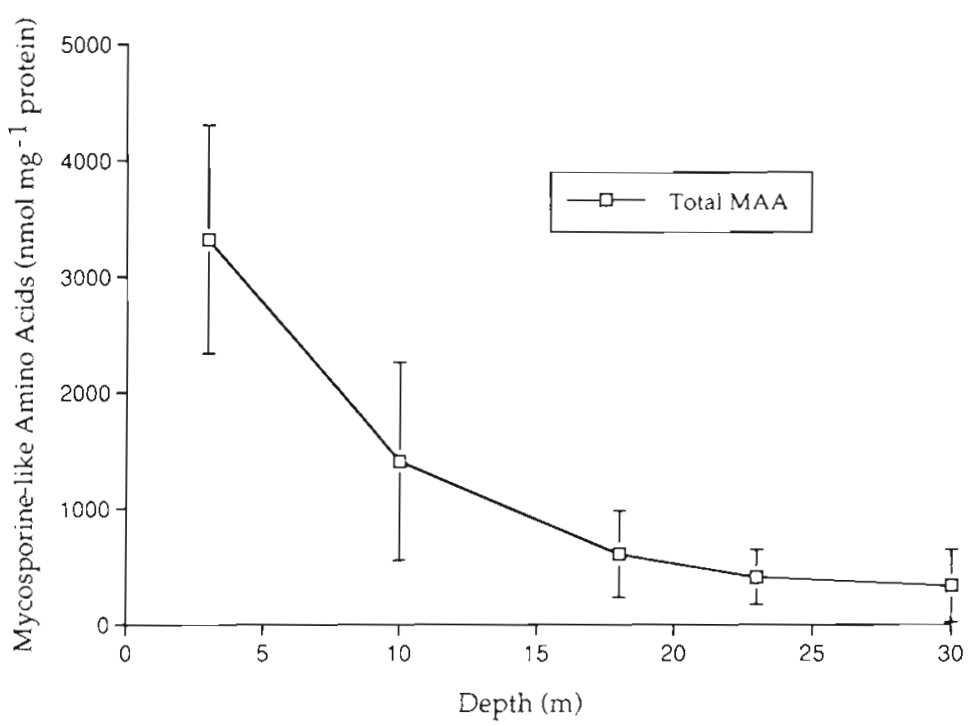

Fig. 3. (Above and facing page) (A) Concentration ( $t$ SD) of individual mycosporine-like amino acids (MAAs) in the coral Montastraea faveolata on Conch Reef. Key Largo, Florida, August 1994, versus water depth. (B) Concentration ( \pm SD) of total. MAAs in the coral M. faveolata on Conch Reef, Key Largo, Florida, August 1994, versus water depth. (C) Regression analysis for the concentrations of total MAAs as a function of UV irradiance for M. faveolata collected on Conch Reef, Key Largo, Flonda, August 1994

was significantly greater at $3 \mathrm{~m}$ than at all other depths (SNK: $p<0.05$ ). No other significant effects of depth were detected in the romaining MAAs. The total concentration of MAAs in corals collected on Conch Reef also decreased significantly with increasing depth (1-way ANOVA, $d f=4,25, F$-value $=8, p=0.0002)$ or decreasing UVR irradiance (Fig. 3B). Total MAA concentration in individual corals of $M$. faveolata from all depths $(\mathrm{N}=30$ ) was regressed against total UVR irra- diance at the depth of collection (Fig. 3C). The significant regression (ANOVA, df $=1,28, F$-value 73, $p<$ $0.0001)$ uñd the hight $\mathrm{R}^{2}$ value $(0.722)$ sugyest that UVR irradiance is a good predictor of MAA concentration for $M$. Iaveolata. When MAA concentration is regressed against both UVR and PAR a significant multiple regression occurs for both independent variables; however, the partial standard coefficients for PAR and UVR were not significant (t-test: $p>0.05)$. 
C

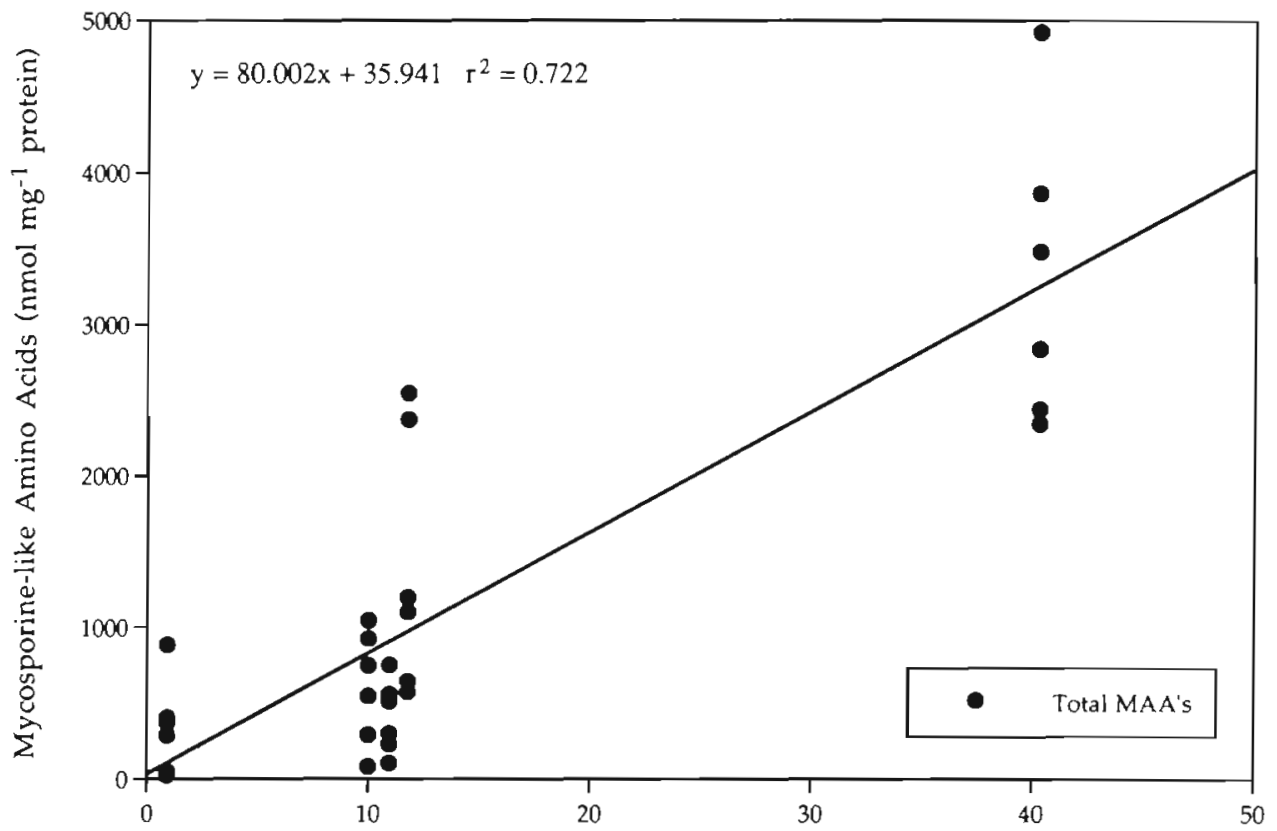

Ultraviolet Radiation $\left(300-400 \mathrm{~nm}, \mathrm{~W} \mathrm{~m}^{-2}\right.$ )

Stepwise regression analysis using either forward or backward elimination procedures detects a significant functional relationship between MAA concentration and UVR (ANOVA: $p<0.0001$ ) while eliminating PAR as an independent variable and significant indicator of MAA concentrations (Sokal \& Rohlf 1981).

\section{Action spectra and radiation amplification factors}

The photosynthesis versus irradiance curves, representing the different WG filter treatments, for all depths showed positive non-linear regression fits with high regression coefficients $\left(R^{2}>0.95\right.$ for all curves). This indicated that most of the variation in the fit was explained by the relationship between photosynthesis and irradiance (data not shown). Estimates of $P_{\max }$ for each filter treatment showed a significant decrease with the addition of sequentially greater portions of the UVR spectrum (1-way ANOVA, df =5, 12, F-value 25, $\mathrm{p}<0.001)$. All post hoc pairwise comparisons of $P_{\max }$ among filter treatments were significantly different from one another (SNK: $p<0.05$ ) except for the comparison between the 280 and $295 \mathrm{~nm}$ filter treatments (SNK: $\mathrm{p}>0.05$ ). The action spectra derived from the photosynthesis-irradiance data and the UVR irradiances, using the exponential equation $\varepsilon(\lambda)=\exp \left(a_{0}+a_{1} \lambda+\right.$ $a_{2} \lambda^{2}$ ) of Rundel (1983), are presented in Fig. 4. A $\chi^{2}$ analysis on each action spectrum showed no significant difference between the measured values (data not shown) used in the exponential equation of Rundel (1983) and fitted values (Table 3) of biological effectiveness. These action spectra, except for $3 \mathrm{~m}$, show a steep and rapid decrease with increasing wavelength. These spectra indicate that shorter wavelengths (UVB and part of the UVA spectrum), with their higher energy content, have a more detrimental effect on photosynthesis in this species of coral at those depths. The $3 \mathrm{~m}$ spectrum suggests that this population of corals exhibits a greater effect of both the UVB and UVA portions of the spectrum on photosynthesis compared to the action spectra on corals from deeper depths. This enhanced sensitivity to UVR in shallow-water corals occurs despite the higher rates of photosynthesis observed in $3 \mathrm{~m}$ corals.

Table 3. Summary of fitted parameters that describe the action spectra derived from the photosynthesis-irradiance data on Montastraea faveolata, Conch Reef, Florida Keys, August 1994, using the exponential equation $\varepsilon(\lambda)=\exp \left(a_{0}+a_{1} \lambda+\right.$ $a_{2} \lambda^{2}$ ) from Rundel (1983) and illustrated in Fig. 4

\begin{tabular}{|lrcrc|}
\hline Depth (m) & \multicolumn{1}{c}{$a_{0}$} & $a_{1}\left(\mathrm{~nm}^{-1}\right)$ & $a_{2}\left(\mathrm{~nm}^{-2}\right)$ & $\mathrm{r}^{2}$ \\
\hline 3 & -13.711 & 0.010419 & -0.00019651 & 0.992 \\
10 & 43.273 & -0.22864 & 0.00027581 & 0.985 \\
18 & 60.247 & -0.33199 & 0.00043079 & 0.975 \\
23 & 61.984 & -0.34222 & 0.00044549 & 0.973 \\
30 & 42.845 & -0.22559 & 0.00027059 & 0.985 \\
$30 \rightarrow 18$ & 58.235 & -0.31799 & 0.00040673 & 0.975 \\
\hline
\end{tabular}




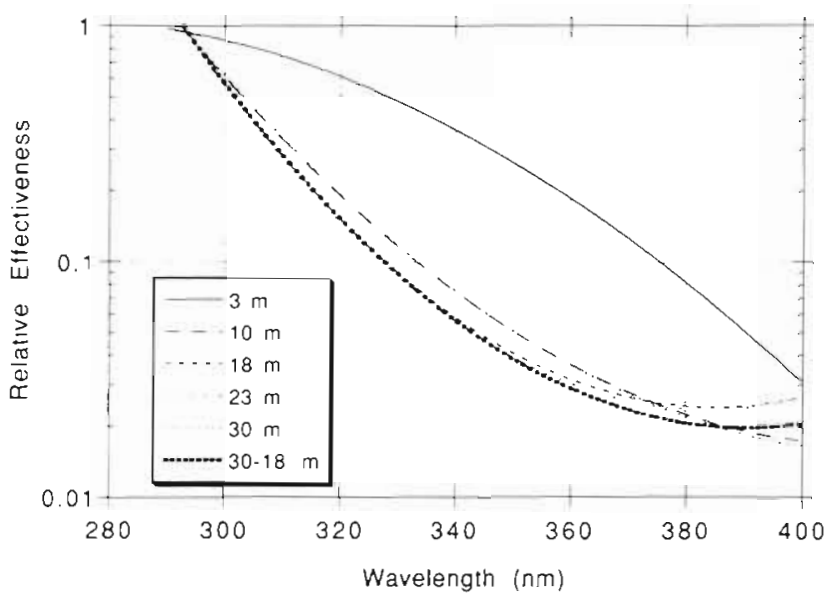

Fig. 4. Polychromatic action spectra (= biological weighting function, 290 to $400 \mathrm{~nm}$ ) for Montastraea faveolata from Conch Reef, Key Largo, Florida, August 1994

These action spectra were then used to calculate RAFs, using a full radiative transfer calculation for the atmosphere and the assumption of similar optical conditions for the overlying water column. The RAFs are also calculated as a function of solar zenith angle and ozone concentration for each depth (Fig. 5) with the mean RAF value for each depth ( \pm the variability with solar zenith angle and ozone concentration). The RAFs, in general, are quite low (0.15 to 0.23) compared to RAFs calculated for DNA damage $(-2.0)$ or the inhibition of photosynthesis in free-living phytoplankton $(\sim 0.5$ to 0.95$)$ and vary little with solar zenith angle and ozone concentration (Madronich 1993). For example, if the RAF derived from Setlow's DNA action spectrum were appicable to corals it would mean that for a given incremental decrease in ozone concentration the effects on DNA will be almost 9 times greater than the effect on photosynthesis in these corals

\section{DISCUSSION}

UVR irradiances, specifically UVB, were measured to a depth of $30 \mathrm{~m}$ on this subtropical coral reef. Using the mean attenuation coefficient for UVB wavelengths (0.22) from this study, the calculated maximum depth for downwelling irradiances of UVB at 1 and $10 \%$ of surface irradiances for the oceanographic conditions encountered during this study are 21 and $11 \mathrm{~m}$ respectively (Kirk 1994b). Despite the natural and anthro pogenic input of dissolved organic and particulate organic material known to occur in coastal reef systems (Kirk 1994a), measurable UVB irradiances are observed over most of the bathymetric distribution of Montastraed faveolata at this study site. The regular occurrence of tidal bores (Leichter et al. 1996) in this habitat is likely to have significant, but transient, effects on the spectral attenuation of UVR and PAR irradiances that are not accounted for in this study.

The action spectra results presented here for Montastraea faveolata, derived from $P$ - $I$ curves using a polychromatic approach, suggest that throughout the bathymetric range of this coral there are measurable effects of present-day ambient UVR on photosynthesis, especially for corals at $3 \mathrm{~m}$. Despite this, corals at $3 \mathrm{~m}$ exhibit significantly higher rates of photosynthesis than conspecifics at deeper depths, even though the UVR irradiances at these shallow depths are much higher. One potential explanation for this is the significant functional relationship between UVR irradiance and MAA concentrations in coral tissues that strongly suggests a protective effect of the host tissues for zooxanthellae in hospite. Despite the fact that PAR irradiances and water flow are known both to co-vary with depth and to influence MAA concentrations (Jokiel et al. 1997), the multiple regression analysis shows that over $70 \%$ of the variation in MAA concentration can be explained by differential exposure to UVR. Similar results have been observed for UVR effects on photosynthesis in the coral Acropora microphthalma from the Great Barrier Reef (Shick et al. 1995).

Other possible explanations for the higher rates of photosynthesis in shallow waters are the presence of protective mechanisms to dissipate the excess energy absorbed in both the UVR and PAR wavelengths, to detoxify by-products of the absorption of UVR, or repair the damage caused by exposure to UVR. These mechanisms include non-photochemical quenching that reemits absorbed photons as fluorescence (685 nm), thus protecting the photosynthetic apparatus from over excitation (Falkowski et al. 1990). Additionally, the xanthophyll cycle involves photoprotective carotenoids that also dissipate the energy of absorbed photons as heat (Falkowski et al. 1990), and the toxic by-products of photosensitization reactions, such as reactive oxygen species, can be scavenged by enzymatic and nonenzymatic mechanisms (Shick et al. 1996). And lastly, the replacement of damaged proteins or repair of DNA damage is an essential component of resistance to UVR-induced damage. Experimental evidence shows that all of these mechanisms are inducible by exposure to high irradiances of UVR. Finally, different genotypes of zooxanthellae, known to exist within one coral host species or over its depth range, could also contribute to

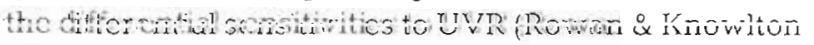
1995, Rowan et al. 1997).

The presence of these protective mechanisms might be responsible for the lower RAF calculated for shallow corals, compared to higher, and virtually indistinguishable, RAFs of conspecifics at deeper depths. The RAFs calculated for Montastraed faveolata at all depths are 
A

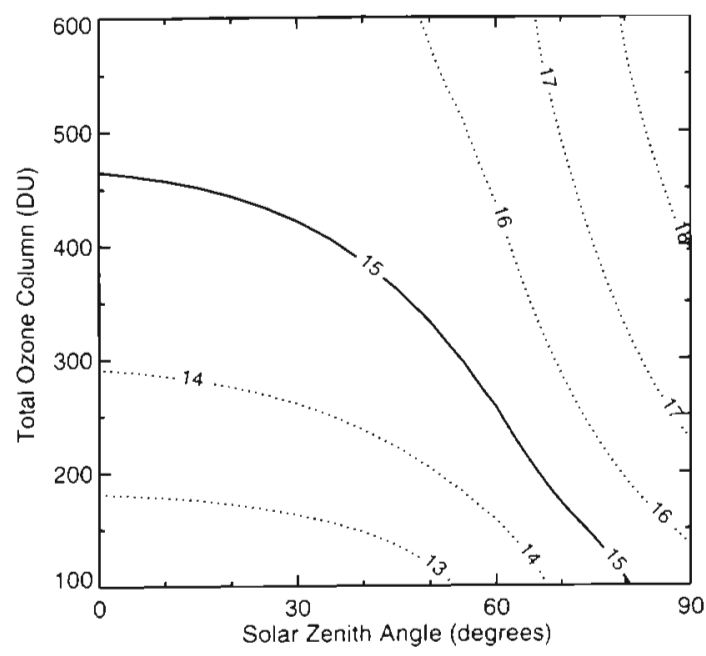

C

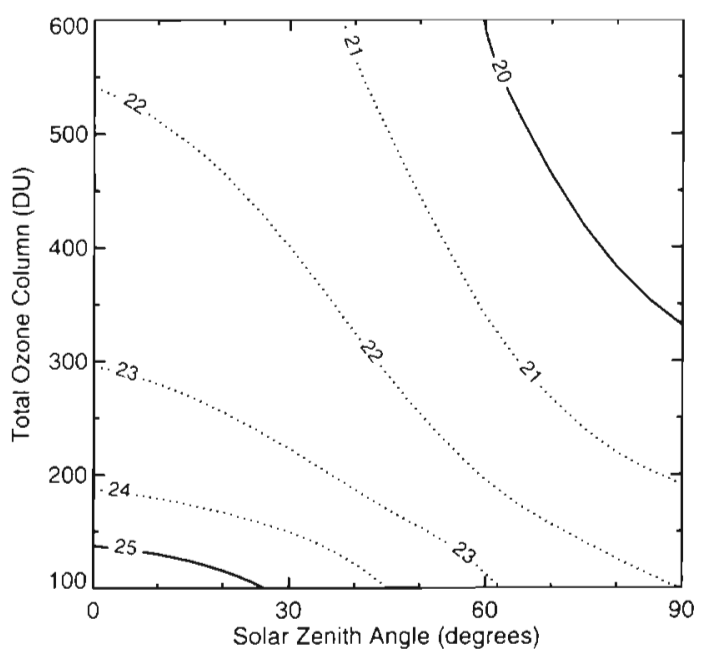

E

Montastraea faveolata, $30 \mathrm{~m}$

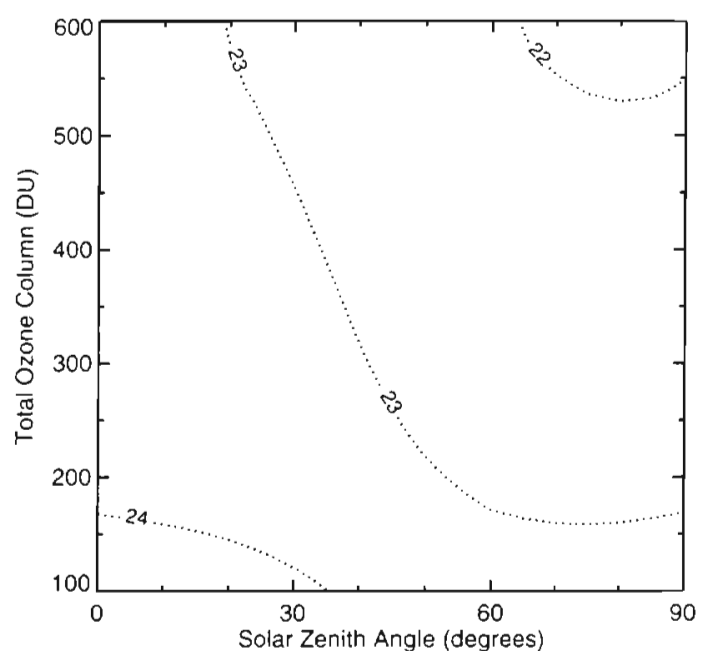

B

Montastraea faveolata, $10 \mathrm{~m}$

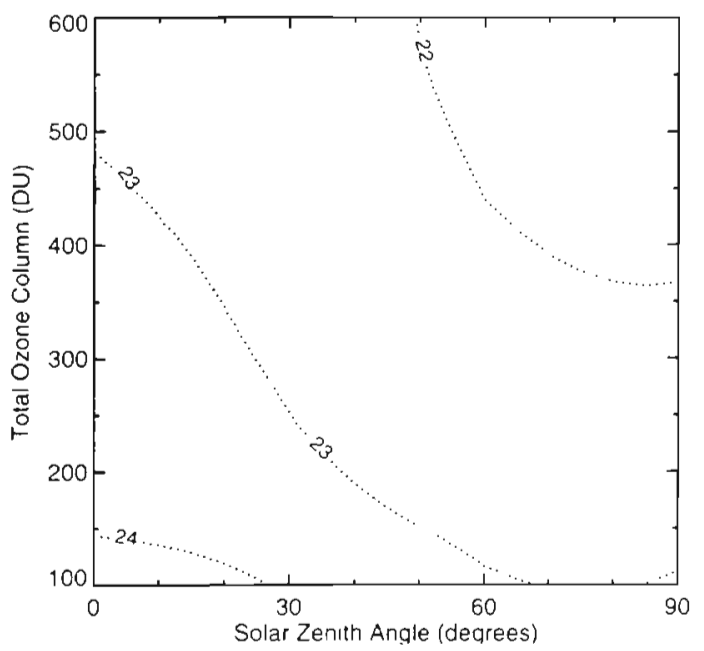

D

Montastraea faveolata, $23 \mathrm{~m}$

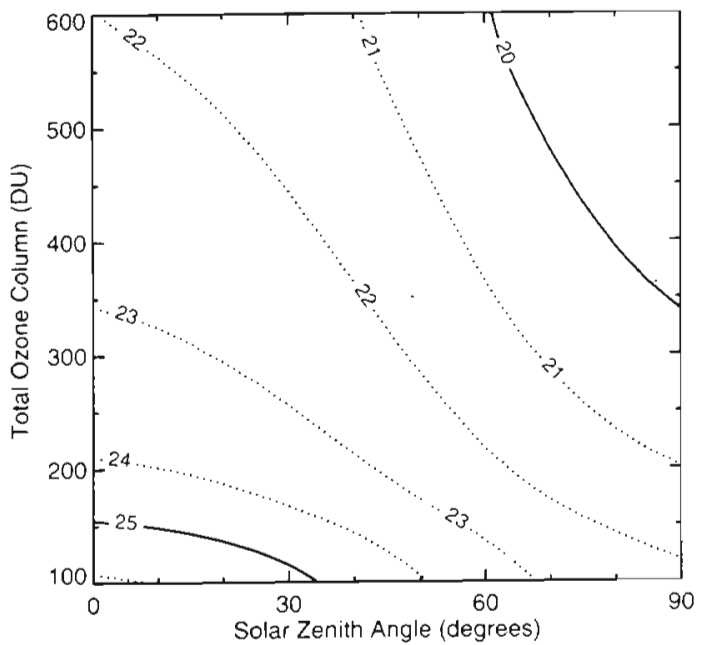

$\mathbf{F}$

Montastraea faveolata, $30->18 \mathrm{~m}$

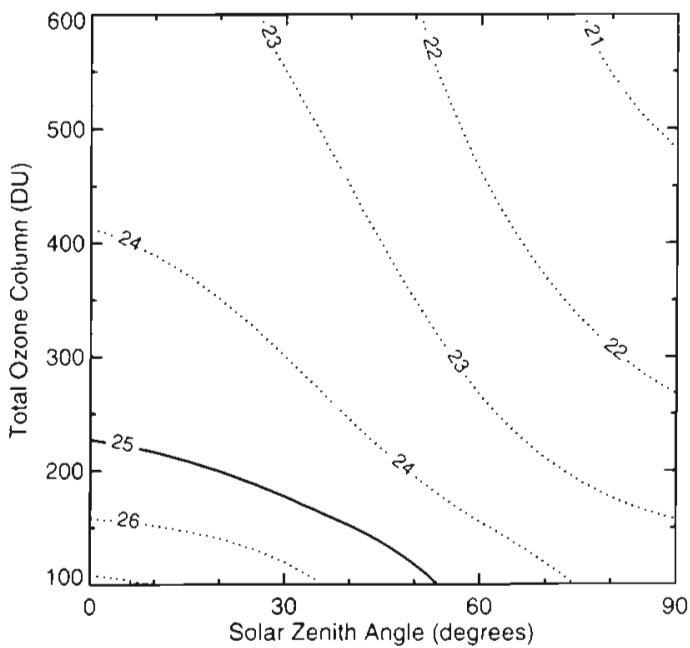

Fig. 5. Radiation amplification factors (RAFs) mean $(\times 100) \pm$ variability associated with solar zenith angle and ozone concentration) for Montastraea faveolata from Conch Reef, Key Largo, Florida, August 1994. (A) $3 \mathrm{~m}, 0.15 \pm 0.02$. (B) $10 \mathrm{~m}, 0.23 \pm 0.01$. (C) $18 \mathrm{~m}, 0.22 \pm 0.02$. (D) $23 \mathrm{~m}, 0.22 \pm 0.02$. (E) $30 \mathrm{~m}, 0.23 \pm 0.01$. (F) $30 \rightarrow 18 \mathrm{~m}, 0.23 \pm 0.02$ 
much lower than published RAFs for DNA damage. Additionally, the RAFs for $M$. faveolata vary little with changes in solar zenith angle and decrease little, or not at all, with changes in ozone concentration. The general lack of sensitivity to changes in ozone concentrations suggests that very large decreases in stratospheric ozone will be required to measure significant additional decreases in photosynthesis by UVR in $M$. faveolata. The lower RAF of corals at $3 \mathrm{~m}$ suggests that these corals will be less sensitive to further stratospheric ozone depletion, and therefore increases in UVR, than their deep-water counterparts. These results seem inconsistent with the action spectrum from $3 \mathrm{~m}$ corals which shows significant UVR effects on photosynthesis. Corals at shallow depths, however, could potentially avoid the effects of future increases in UVR on photosynthesis by employing the repair and protective strategies described above. Their already high exposures to solar UVR and high rates of photosynthesis suggest that this may already be occurring under current irradiances of UVR

A significant depression of photosynthesis was also observed in corals transplanted from 30 to $18 \mathrm{~m}$ compared to corals at $18 \mathrm{~m}$. This change in depth results in at least a 3-fold increase in PAR irradiances but a greater than 30 -fold increase in UVB irradiances (Table 1) with PAR:UVR ratio changes that simultaneously increase the irradiance of UVR and decrease the amount of visible radiation available to stimulate repair mechanisms (e.g. DNA repair). When combined with the lower MAA concentrations in $30 \mathrm{~m}$ corals the higher irradiances of UVR at $18 \mathrm{~m}$ are likely to have contributed to the lower rates of photosynthesis. The results in this case, however, are confounded by not being able to separate the effects of increasing PAR irradiances from UVR effects. The transplant component of this work, however, is still very instructive. Despite the significant decreases in photosynthesis from this acute UVB exposure for the transplants, the biological weighting function for the UVR photoinhibition of photosynthesis and RAFs for the transplanted corals are no different from corals at 10,18,23, and $30 \mathrm{~m}$. This suggests that a large change in UVB exposure would need to occur in order to affect corals at depths greater than $5 \mathrm{~m}$

To further illustrate this point Shick et al. (1996) used the UVB data of Cutchis (1974) for $20^{\circ} \mathrm{N}$ latitude and showed that the cumulative loss of stratospheric ozone ir urn 19569 iv 2006 coulu ve do inuch as $14.6 \%$, which, using the RAF from the coral Pocillopora damicornis for the inhibition of photosynthesis (Lesser \& Lewis 1996) and an RAF calculated for DNA damage, could theoretically expose corals at $1 \mathrm{~m}$ depth to a $3.2 \%$ greater photosynthesis-weighted UVR dose, and a $37.8 \%$ higher DNA-weighted UVR dose, than in 1969.
Because of the polychromatic approach taken to construct the photosynthesis action spectra, and the in situ conditions under which the measurements were taken, the increases in biologically weighted UVR doses can be translated into the maximum potential effects on photosynthesis given that all conditions are similar The analysis of the data on photosynthesis also suggested that even if this increase were to exceed the $L_{50}$ of reef corals now living at $1 \mathrm{~m}$, individuals living at a depth of $2 \mathrm{~m}$ would not be affected because the 1969 maximum dose at $1 \mathrm{~m}$ would never be exceeded

Applying similar calculations to the data on Montastraea faveolata from $3 \mathrm{~m}$ for the period 1969 to 1998 . ozone depletion could be as much as $11.6 \%$, which would expose corals at a depth of $1 \mathrm{~m}$ to a $1.9 \%$ greater photosynthesis-weighted dose of UVB radiation. For corals from Conch Reef, given the same oceanographic regime, in the year 2008 the amount of ozone depletion could be as much as $15.6 \%$, which would expose corals at a depth of $1 \mathrm{~m}$ to a $2.4 \%$ greater photosynthesisweighted UVR dose. In 2008 corals at $2 \mathrm{~m}$ would exceed the maximum 1969 weighted dose at $1 \mathrm{~m}$ in May through August, whereas corals at $3 \mathrm{~m}$ would never see the estimated maximum 1969 weighted dose at $1 \mathrm{~m}$ at any time of the year This analysis suggests that, for corals living at depths greater than $5 \mathrm{~m}$, the present forecasts of ozone depletion in tropical and subtropical areas predict no significant effects of UVR on photosynthesis, and therefore a decreased likelihoad of any effects on growth and reproduction in this species of coral.

So, will decreasing levels of stratospheric ozone be important for coral reefs? Maybe. Several studies, laboratory and field, have demonstrated clear organismal effects of exposure to UVR in zooxanthellate cnidarians (Jokiel 1980, Jokiel and York 1982, 1984, Siebeck 1988, Lesser \& Shick 1989, Gleason \& Wellington 1993, Kinzie 1993, Shick et al. 1995, 1996, Lesser 1996). The in situ work on Pocillopora damicornis (Lesser \& Lewis 1996) and Montastraea faveolata (this study) show that corals exhibit photoinhibition of photosynthesis by UVR. Using the action spectrum for the inhibition of photosynthesis for $M$. faveolata at $3 \mathrm{~m}$ and a typical spectral irradiance for $3 \mathrm{~m}$ at $\mathrm{ca} 13: 00 \mathrm{~h}$ on Conch Reef, the integrated biologically effective (= weighted) dose of UVB from 300 to $320 \mathrm{rm}$ is $4.02 \mathrm{~W} \mathrm{~m}^{-2}$. This value is almost twice that reported for $P$. damicornis at $1 \mathrm{~m}$ in Kaneohe

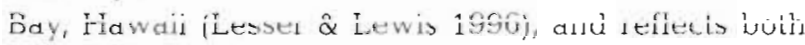
the differences in the action spectra and the optical properties of the overlying water column (Kirk 1994a). in order to calculate and compare the biologically effective dose of UVR affecting corals found at the same depth from different locations using action spectra, even if the action spectra between corals is 
similar, the optical properties of the overlying water column for UVB transmittance must be known.

We do not know the full range of acclimatization capacities of corals exposed to increasing doses of UVR irradiance, but even more important than identifying the effects of UVR on the adult life-history phase would be to fully understand the effects of UVR on the early life-history phases, specifically planula larvae, of corals. Initial studies have shown that pelagic, rapidly developing larvae are more sensitive than their adult counterparts (Gleason \& Wellington 1995). In addition to the natural variability in larval supply (Wallace 1985, Richmond 1996), exposure to sublethal or lethal doses of UVR could dramatically effect larval abundance throughout the bathymetric range of corals with presently unknown consequences.

In the context of continuing ozone depletion, the projected increases of UVB, and the independent effects of that UVB radiation on photosynthesis in corals, may be relatively small. If, however, the acclimatization capacity of corals is exceeded, a small increase could have significant effects. The immediate concern, however, should be the synergistic role that UVR can have with other perturbations of the environment, specifically regional elevations of water temperature known to cause bleaching (Glynn 1991, 1993). It has been shown for different species of symbiotic cnidarians experimentally exposed to elevated temperatures that the bleaching response is enhanced by exposure to UVR (Lesser et al. 1990, Glynn et al. 1994). Independently, the occurrence of El Niño-Southern Oscillation (ENSO) events produces regional warming throughout the Pacific Ocean that causes bleaching events (Glynn 1991, 1993). In areas affected by ENSO events, and other areas where increases in water temperature have been recorded during bleaching events, doldrum conditions often co-occur at the same time and produce lower wind velocities and decreased vertical mixing of the water column. This can cause an increase in water clarity and a decrease in the attenuation of UVR. These conditions could increase the incidence and severity of bleaching events in shallow water coral reef systems (Gleason \& Wellington 1993). Understanding the long-term effects of these regional and global changes in weather and climate on the community ecology of coral reefs will require continued long-term monitoring and multi-factorial experimental studies.

Acknowledgements. I thank the saturation crew (Geoff Trusell, Steven Miller, Elizabeth Kintzing, Rick Biché, and Douglas Kessling [NOAA Habitat Technician]) and the surface support crew (Larry Neveu, Dave Simonelli, Pamela Bradley, Dave Ward [NOAA-NURP], and Brooke Barnes [NOAA-NURP]) for assistance. The RAF calculations were generously provided by Sasha Madronich, National Center for Atmospheric Research, Boulder, Colorado. This manu- script was greatly improved by the comments of an anonymous reviewer. This work was funded in part by a grant from the NOAA National Undersea Research Program administered through the National Undersea Research Center at Wilmington, North Carolina. The views expressed herein are those of the author and do not necessarily reflect the views of NOAA or any of its subagencies. M.P.L. was also supported by the National Science Foundation, Biological Oceanography Program (OCE-9216307/OCE-9496082)

\section{LITERATURE CITED}

Battey JF, Porter JF (1988) Photoadaptation as a whole organism response in Montastrea annularis. In: Choat $\mathrm{JH}$ et al. (eds) Proceedings of the 6th International Coral Reef Symposium, Australia, Vol 3. Symposium Executive Committee, Townsville, p 79-87

Bradford MM (1976) A rapid and sensitive method for the quantitation of microgram quantities of protein using the principle of protein-dye binding. Anal Biochem 72:248-254

Caldwell MM, Camp LB, Warner CW, Flint SD (1986) Action spectra and their key role in assessing biological consequences of solar UV-B radiation change. In: Worrest $\mathrm{RC}$, Caldwell MM (eds) Stratospheric ozone reduction, solar ultraviolet radiation and plant life. Springer-Verlag, New York, p 87-111

Coohill TP (1989) Ultraviolet action spectra (280 to $380 \mathrm{~nm}$ ) and solar effectiveness spectra for higher plants. Photochem Photobiol 50:451-457

Cutchis P (1974) Stratospheric ozone depletion and solar ultraviolet radiation on earth. Science 184:13-19

Cutchis P (1982) A formula for comparing annual damaging ultraviolet (DUV) radiation doses at tropical and mid-latitude sites. In: Calkins $J$ (ed) The role of solar ultraviolet radiation in marine ecosystems. Plenum Press, New York, p 213-228

Dubinsky Z, Falkowski PG, Porter JW, Muscatine L (1984) Absorption and utilization of radiant energy by light-and shade-adapted colonies of the hermatypic coral Stylophora pistillata. Proc R Soc Lond B 222:203-214

Dunlap WC, Chalker BE (1986) Identification and quantitation of near-UV absorbing compounds (S-320) in a hermatypic scleractinian. Coral Reefs 5:153-159

Dunlap WC, Chalker BE, Oliver JK (1986) Bathymetric adaptations of reef-building corals at Davies Reef, Great Barrier Reef, Australia. III. UV-B absorbing compounds. J Exp Mar Biol Ecol 104:239-248

Dunne RP, Brown BE (1996) Penetration of solar UVB radiation in shallow tropical waters and its potential biological effects on coral reefs; results from the central Indian Ocean and Andaman Sea. Mar Ecol Prog Ser 144:109-118

Dustan P (1982) Depth-dependent photoadaptation by zooxanthellae of the reef coral Montastrea annularis. Mar Biol 68:253-264

Falkowski PG, Jokiel PL, Kinzie RA III (1990) Irradiance and corals. In: Dubinsky Z (ed) Coral reefs, ecosystems of the world, Vol 25. Elsevier, Amsterdam, p 89-107

Fleischmann EM (1989) The measurement and penetration of ultraviolet radiation into tropical marine water. Limnol Oceanogr 34:1623-1629

Frederick JE, Snell HE, Haywood EK (1989) Solar ultraviolet radiation at the earth's surface. Photochem Photobiol 50: $443-450$

Gleason DF (1993) Differential effects of ultraviolet radiation on green and brown morphs of the Caribbean coral Porites astreoides. Limnol Oceanogr 38:1452-1463 
Gleason DF, Wellington GM (1993) Ultraviolet radiation and coral bleaching. Nature 365:836-838

Gleason DF, Wellington GM (1995) Variation in UVB sensitivity of planula larvae of the coral Agaricia agaricites along a depth gradient. Mar Biol 123:693-703

Glynn PW (1991) Coral reef bleaching in the 1980s and possible connections with global warming. Trends Ecol Evol 6: $175-179$

Glynn PW (1993) Coral reef bleaching: ecological perspectives. Coral Reefs 12:1-17

Glynn PW, Imai R, Sakai K, Nakano Y, Yamazato K (1994) Experimental responses of Okinawan (Ryukyu Islands, Japan) reef corals to high sea temperature and UV radiation. In: Richmond $\mathrm{R}$ (ed) Proceedings of the 7 th Coral Reef Symposium, Guam. University of Guam, Mangilao, p 27-37

Green AES, Sawada T, Shettle EP (1974) The middle ultraviolet reaching the ground. Photochem Photobiol 19:251-259

Jassby AD, Platt T (1976) Mathematical formulation of the relationship between photosynthesis and light for phytoplankton. Limnol Oceanogr 21:540-547

Jeffrey SW, Humphrey GF (1975) New spectrophotometric equations for determining chlorophylls $a_{1} b_{1} c_{1}$ and $c_{2}$ in higher plants, algae and natural phytoplankton. Biochem Physiol Pflanz 167:191-194

Jerlov NG (1950) Ultra-violet radiation in the sea. Nature 166: $111-112$

Jokiel PL (1980) Solar ultraviolet radiation and coral reef epifauna. Science 207:1069-1071

Jokiel PL, York RH Jr (1982) Solar ultraviolet photobiology of the reef coral Pocillopora damicornis and symbiotic zooxanthellae. Bull Mar Sci 32:301-315

Jokiel PL, York RH Jr (1984) Importance of ultraviolet radiation in photoinhibition of microalgal growth. Limnol. Oceanogr 29:192-199

Jokiel PL, Lesser MP. Ondrusek ME (1997) UV-absorbing compounds in the coral Pocillopora damicornis: interactive effects of UV radiation, photosynthetically active radiation, and water flow. Limnol Oceanogr 42:1468-1473

Kınzie RA III (1993) Effects of ambient levels of solar ultraviolet radiation on zooxanthellae and photosynthesis of the reef coral Montupora verrucosa. Mar Biol 116:319-327

Kirk JTO (1994a) Optics of UV-B radiation in natural waters. Arch Hydrobiol Beih Ergebn Limnol 43:1-16

Kirk JTO (1994b) Light and photosynthesis in aquatic ecosystems. Cambridge University Press, London

Kırk JTO, Hargreaves DP, Morris R, Coffin R, Fredrickson DB, Karentz D, Lean D, Lesser MP, Madronich S, Morrow JH, Nelson N, Scully N (1994) Measurements of UV-B radiation in two freshwater lakes: an instrument intercomparison. Arch Hydrobiol Beih: Ergebn Limnol 43:71-99

knowlton N, Weil E, Weigt LA, Guzmán HM (1992) Sibling species in Montastraea annularis, coral bleaching, and the coral climate record. Science 255:330-333

Leichter JJ, Wing SR, Miller SL, Denny MW (1996) Pulsed delivery of subthermocline water to Conch Reef (Florida Keysi by internal tidal bores. Limnol Oceanogr 41 : $1490-1501$

Lesser MP (1996) Exposure of symbiotic dinoflagellates to elevated temperatures and ultraviolet radiation causes oxidative stress and inhibits photosynthesis. Limnol Oceanogr $41: 271-283$

Lesser MP, Lewis S (1996) Action spectra for the inhibition of photosynthesis by ultraviolet radiation in the hermatypic cora! Pocillopora damicornis. Mar Ecol Prog Ser 134: $171-177$

Lesser MP Shick JM (1989) Effects of irradiance and ultravio- let radiation on photoadaptation in the zooxanthellae of Aiptasia pallida: primary production, photoinhibition, and enzymic defenses against oxygen toxicity. Mar Biol 102: $243-255$

Lesser MP, Stochaj WR, Tapley DW, Shick JM (1990) Bleaching in coral reef anthozoans: effects of irradiance, ultraviolet radiation and temperature, on the activities of protective enzymes against active oxygen. Coral Reefs 8: $225-232$

Lesser MP, Cullen JJ, Neale PJ (1994) Photoinhibition of photosynthesis in the marine diaton Thalassiosira pseudonana during acute exposure to utraviolet $\mathrm{B}$ radiation: relative importance of damage and repair. J Phycol 30:183-192

Madronich S (1993) UV radiation in the natural and perturbed atmosphere. In: Tevini M (ed) UV-B radiation and ozone depletion, effects on humans, animals, plants, microorganisms, and materials. Lewis Publishers, Boca Raton, FL, p $17-70$

Madronich S (1994) Increases in biologically damaging UV-B radiation due to stratospheric ozone reductions: a brief review. Arch Hydrobiol Beih: Ergebn Limnol 43:17-30

Madronich S, McKenzie RL, Caldwell MM, Björn LO (1995) Changes in ultraviolet radiation reaching the earth's surface. Ambio 24:143-152

Marsh JA (1970) Primary productivity of reef-building calcareous algae. Ecology 51:255-263

Muscatine L (1990) The role of symbiotic algae in carbon and energy flux in reef corals. In: Dubinsky Z (ed) Coral reefs, ecosystems of the world, Vol 25. Elsevier, Amsterdam, p $75-87$

Porter JW (1985) The maritime weather of Jamaica: its effects on annual carbon budgets of the massive reef-building coral Montastrea annularis. In: Delesalle B et al. (eds) Proceedings of the 5th International Coral Reef Symposium, Tahiti, Vol 6. Antenne Museum-EPHE, Moorea, p 363-379

Porter JW. Muscatine L, Dubinsky Z, Falkowski PG (1984) Primary production and photoadaptation in light-and shadeadapted colonies of the symbiotic coral, Stylophora pistillata. Proc R Soc Lond B 222:161-180

Richmond RH (1996) Reproduction and recruitment in corals: critical links in the persistence of reefs. In: Birkeland $C$ (ed) Life and death of coral reefs. Chapman and Hall, New York, p 175-196

Rowan R, Knowlton N (1995) Intraspecific diversity and ecological zonation in coral-algal symbiosis. Proc Natl Acad Sci $92: 2850-2853$

Rowan R, Knowlton N, Baker A, Jara J (1997) Landscape ecology of algal symbionts creates vanation in episodes of coral bleaching. Nature 388:265-269

Rundel RD (1983) Action spectra and estimation of biologically effective UV radiation. Physiol Plant 58:360-366

Scelfo ( $: 1$ (1986) Relationship between solar radiation and pigmentation of the coral Montipora verrucosa and its zooxanthellae. In: Jokiel PL, Richmond RH, Rogers RA (eds) Coral reef population biology. Hawaii Inst Mar Biol Tech Rep 37. University of Hawaii, Honolulu, p 440-451

Setlow RB (1974) The wavelengths in sunlight effective in producing skin cancer: a theoretical analysis. Proc Natl Acad Science 71:3363-3366

Shick JM, Lesser MP, Stochaj WR (1991) Ultraviolet radiation and photooxidative stress in zooxanthellate Anthozod: the sea anemone Phyllodiscus semoni and the octocoral Clavularia sp. Symbiosis 10:145-173

Shick JM, Dunlap WC, Chalker BE, Banaszak AT, Rosenzweig TK (1992) Survey of ultraviolet radiation-absorbing mycosporine-like amino acids in organs of coral reef holothuroids. Mar Ecol Prog Ser 90:139-148 
Shick JM, Lesser MP, Dunlap WC, Stochaj WR, Chalker BE, Wu Won J (1995) Depth-dependent responses to solar ultraviolet radiation and oxidative stress in the zooxanthellate coral Acropora microphthalma. Mar Biol 122 $41-51$

Shick JM, Lesser MP, Jokiel PL (1996) Effects of ultraviolet radiation on corals and other coral reef organisms. Global Change Biol 2:527-545

Siebeck O (1988) Experimental investigation of UV tolerance in hermatypic corals (Scleractinia). Mar Ecol Prog Ser 43: 95-103

Smith RC, Baker KS (1979) Penetration of UV-B and biologically effective dose-rates in natural waters. Photochem Photobiol 29:311-323

Smith RC, Baker KS, Holm-Hansen O, Olson RS (1980) Photo-

Editorial responsibility: Otto Kinne (Editor),

Oldendorf/Luhe, Germany inhibition of photosynthesis in natural waters. Photochem Photobiol 31:585-592

Sokal RR, Rohlf FJ (1981) Biometry. WH Freeman and Co, New York

Stolarski R, Bojkov R, Bishop L, Zerefos C, Zawodny J (1992) Measured trends in stratospheric ozone. Science 256: $342-349$

Wallace CC (1985) Seasonal peaks and annual fluctuations in recruitment of juvenile scleractinian corals. Mar Ecol Prog Ser 21:289-298

Weil E, Knowlton N (1994) A multi-character analysis of the Caribbean coral Montastraea annularis (Ellis and Solander, 1786) and its two sibling species, M. faveolata (Ellis and Solander, 1786) and M. franksi (Gregory, 1895). Bull Mar Sci 55:151-175

Submitted: November 19, 1998; Accepted: August 2, 1999 Proofs received from author(s): January 5, 2000 